\title{
道路建設の切土区間における 地下水環境保全のための復水工法の検討
}

\author{
永井 宏 ${ }^{1}$ - 西垣 誠 ${ }^{2}$ - 宇野尚雄 ${ }^{3}$ - 柳田三徳 ${ }^{4}$ \\ ${ }^{1}$ 正会員 日本道路公団新潟建設局系魚川工事事務所（干941 糸魚川市本町 7-1） \\ ${ }^{2}$ 正会員 工博 岡山大学教授 環境理工学部環境デザイン工学科（テ700 岡山市津島中 3-1-1） \\ 3正会員 工博 岐阜大学教授 工学部土木工学科（テ501-11 岐阜市柳戸1-1） \\ ${ }^{4}$ 正会員 日本工営梸大阪支店（干530 大阪市北区堂島浜 $2-1-29$ )
}

切土構造を有する道路計画が既存の帯水層を分断する場合，地下水環境保全の見地から，地下水下流側 の地下水位を現状に近い状態に復元させることを目的に復水工法を計画した．本工法は『逆サイフォン』 による復水を基本システムとしており，本工法の有効性の確認，規模及び基本形式を決定するに当たって は種々の原位置調查試験及び数値解析によるシミュレーションを用い検討を進めた。 本工法は大口径の集 水・婳養井戸を設置し，さらに浸透断面積を大きくする手法を組み合わせていることに特徴がある.

Key Words : groundwater preservation method,recharge well,clogging of well, water passage

\section{1.はじめに}

今日では建設工事における地下水環境保全は，きわ めて重要な課題になってきている，一般に, 地下水の 保全対策として復水工法が有効である. しかし帯水層 内に地下水を復水する際には種々の問題があり, それ らの問題を解決しなければ, 恒久的な復水工法を採用 することは困難である.

たとえば短期の建設工事において地下水位低下工法 による地盤沈下や井戸の枯渴等といった地下水障害の 防止のために復水工法が施工された実例はあるが，そ の時にも復水能力の低下のためにより, 逆洗浄が何回 か行なわれていることが多い11，21，31．

このような復水工法における復水機能の低下要因と して, 次のような事項が考えられている.

（1）注入水中の懸濁物及び空気

（2）帯水層内での化学反応

（3）井戸または帯水層内での微生物の増加

（4）帯水層に水を注入する時に起こる帯水層中の 土粒子配列の変化

したがって，これら種々の機能低下の要因を克服する ことによって, 恒久的な地下水環境保全対策工法が有 効になってくると考えられる.

本研究では，掘割構造を有する道路建設工事に伴う 地下水障害を未然に防ぐための地下水保全対策を検討 した. 特に本稿では, 現地の地下水状況を反映したシ
ミュレーション解析により工法の妥当性を評価し, 試 験施工によりその有効性を確認した結果と，恒久的な 復水施設を設計・施工する際の理念について論述する.

\section{2. 復水工法選択の概要}

当該地区での道路構造は, 前後の縦断線形及び周辺 地域に対する環境的配慮から7叫 10m程度の切土構造で 計画された. 一般に切土, 掘割構造として図一 1 に示 す 4 つのケースが考えられる.この中で (d) が確実 な掘割構造であるが，施工費等の面で有利な（b）の 構造を採用し，この構造に対し復水工法を検討するこ ととした．すなわち，（a）は地下水位が高い当該地 区では不可能であり，（c）は山留めが十分に安定で ある必要があるため施工費が高くなる，原位固のボー リング調查結果から掘削底面下に粘土層があるため （b）の構造で底面の浸透圧さえ考慮すれば施工が十 分可能であると判断した. 図一 2 に当該地区の地質断 面図を示す，原位固で地下水位を計測すると， $\mathrm{Tm} \mathrm{g}$ 層 之0g層に地下水が存在し, 特に $\mathrm{Tm}$ g層では地表面下 1 2mに自由水面があり，この地下水は農業用水や家 庭の雑用水として利用されている.このような地形で 図ー1の（b）の構造を用いると道路によりT m g層を 完全に分断してしまう. したがって道路建設において 地下水障害を防止するためには, 上流から下流へ地下 水を通水する道を形成する復水工法による保全対策が 


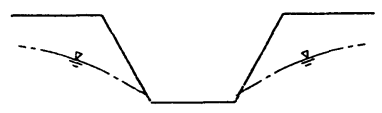

(a)
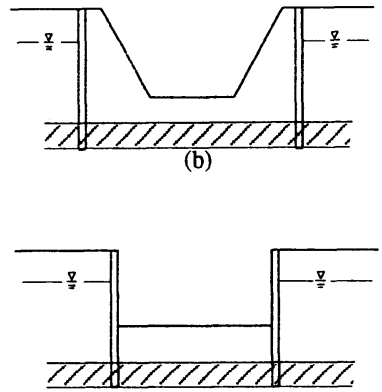

(c)

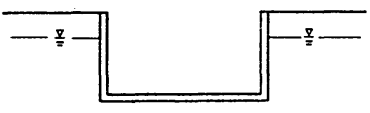

(d)

図一 1 切土・掘割構造例

必要となった. その為に道路建設工事周辺の地盤, 地 下水調查を行なった。

\section{3. 地盤・地下水調査}

\section{(1) 概況}

現況を把握するために，計画ルート周辺域に対する 既存資料の整理及び地表踏查，井戸台帳作成，井戸測 水調查, 水質分析, ため池調查等を実施し, 水理地質, 地下水賦存状況及び地下水流動状況等を検討した。

更に，ルート周辺でのボーリング調査，現場透水試 験，揚水試験等を実施し，帯水層の分布状況やその水 理特性を検討した。 また試験掘りも行い，地下水の涌 水状況と切土のり面の安定性について観察した。

\section{（2）水理地質構造}

計画ルート周辺の地形は，図ー2, 図ー3に示すよ うに両端の 2 つ河川により形成された高位，中位及 び低位の 3 つの段丘面が識別され，切土区間には主に 中位段丘面が広がっている. 地質は新第三紀鮮新世後 期〜第四紀洪積世の堆積物である大阪層群之，これを 不整合に復って分布する段丘堆積物に分けられる．大 阪層群は未固結の粘土，砂，磷及びこれらの互層から 構成されており, 砂及び僺層は被圧帯水層となってい る. 一方段丘堆積物は粘性土，砂，砂磁之場所による 層相变化が著しいが，砂及び砂砂層は浅部の不圧帯水 層を形成し，周辺浅井戸の取水層となっている.

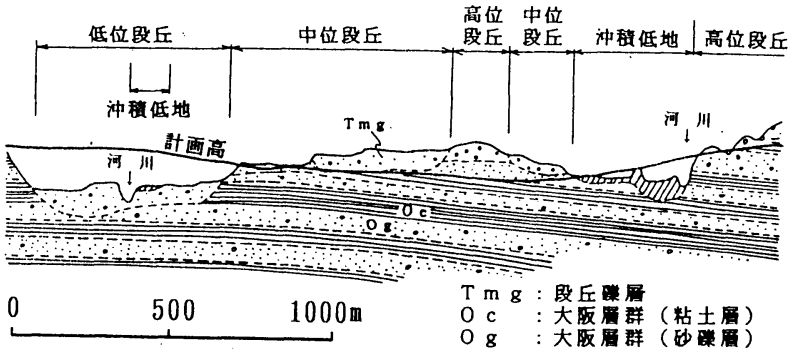

図-2 道路計画路線沿いの地質断面図

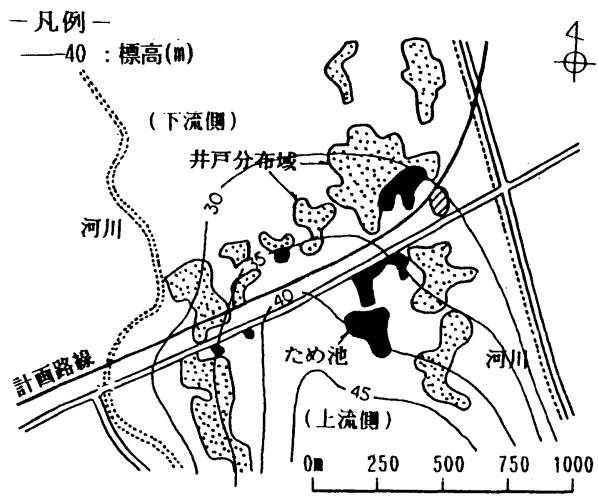

図-3 道路計画路線の平面図

揚水試験により求めた透水係数は，段丘砂磷層で 4. $3 \times 10^{-3} \mathrm{~cm} / \mathrm{sec}$, 大阪層群の砂層で $1.6 \times 10^{-3} \mathrm{~cm} / \mathrm{sec}$ であり, 砂喽層の透水係数としては比較的小さな値と なっている. ただし首相変化から見て局所的に大きな 透水性を有する層が存在すると判断した。

\section{（3）地下水賦存・流勤状況}

計画ルート周辺の地下水の分布状況と流動状況を把 握する目的で， 8 年間既設井戸とため池を対象に水文 ・地下水調查を実施している.

段丘啋層中の自由地下水は年間平均GL-1～2mの浅所 に分布し，概ね地形形状に従い両端の河川に向かって 計画ルートを横切る形で放射状に約1/60の動水勾配で 流動している. そして冬季 (12～2月）には夏季（6 〜8月）に比較して $1.5 \mathrm{~m}$ 程度の地下水位低下が見られ る.

一方大阪層群の砂及び碟層の地下水の水頭は, 上部 の自由地下水に比較して 0.4 2.0m低く分布しており, 自然状態のポテンシャルとしては自由地下水の方が高 い状態にある.

\section{（4）周辺の水利用状況}

周辺地域では殆どの地区で上水道が普及しているが, 井戸は生活用水, 灌溉用水として高頻度で利用されて いる．表ー 1 に示すように，井戸は計画ルート周辺に 計2 55 ヶ所確認されている.これらの井戸の大半はい 
表一 1 水利用施設の状況

\begin{tabular}{|c|c|c|c|}
\hline \multicolumn{2}{|c|}{ 水利用施設 } & 分布規模 & 備 \\
\hline 井 & 浅井戸 & 245 ヶ所 & このうち58ヶ所はかんがい用 \\
\hline 戸 & 深井戸 & 10ヶ所 & 大阪層群から取水 \\
\hline & め 池 & 8 ヶ所 & 総眝水容量 $128,000 \mathrm{~m}^{3}$ \\
\hline
\end{tabular}

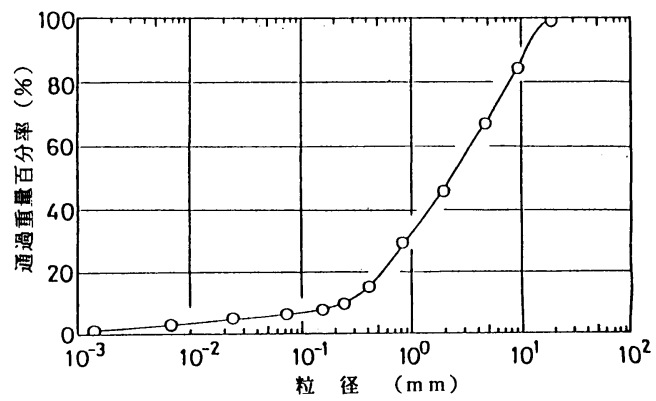

図－4 粒径加積曲線（段丘砂碟の原位置土）

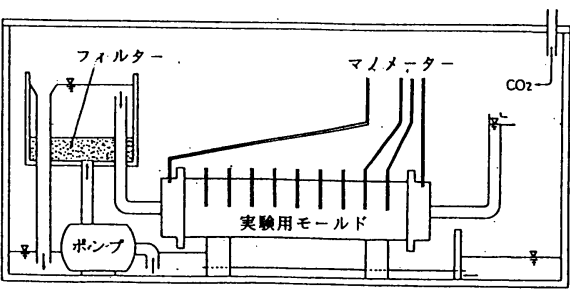

図－５室内浸透実験試験設備

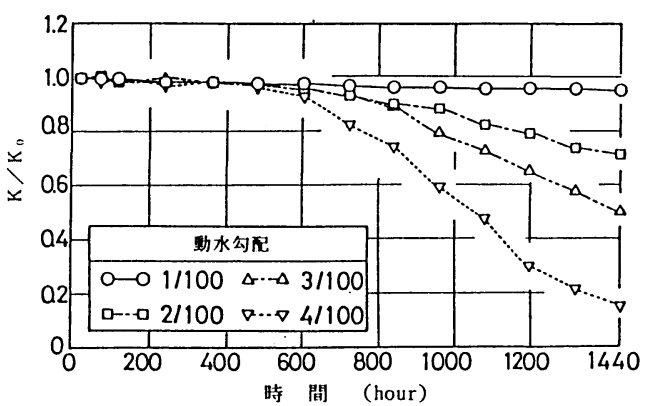

図-6 透水係数の経時変化

実験結果の一例を図ー6に示す. 図中の縦軸は流出 流量より逆算して供試体の透水係数の初期の值に対す る比を示している。これより $2 / 100$ 以上の動水勾配で は実験開始後 600 時間から試料の透水性が小さくなる 傾向が見られ，目詰まりの発生が認められた。即ち目 詰まりを起こさない動水勾配の上限は $1 / 100$ 程度と考 えられる. しかし現地における自由地下水の動水勾配 はこれより大きい1/60程度である。このことから，実 際地盤では地下水は固定された『水みち』に支配され て流動していると解釈される. 即ち, 実験に用いた擋 乱試料では均質に充填しているので, この水みちが再 現されておらず，より小さな動水勾配で目詰まりが生 じたものと考えられる. 従って自然堆積状態の土に対 しては，室内でのこのような目詰まり実験で現地の地 下水流動を再現し, 定量的評価を行なうことは困難で あることがわかった。

\section{（6）試験掘り結果}

道路は当地域を延長約 $1.3 \mathrm{~km}$, 切土高約 $8 \mathrm{~m}$ で計画さ れている.このため, 実際の切土工事を想定して原位

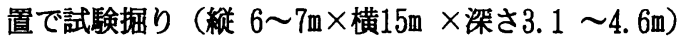
を行なった。その結果地下水位よりも上位の掘削面は 安定を保持するものの, 地下水位よりも下位の段丘磷 層の出現するのり面では地下水涌出に伴う啋層基質部 の逸脱が認められ，小規模な崩落が随時発生し，無対 策では切土のり面の安定維持が困難であることが分か った. 


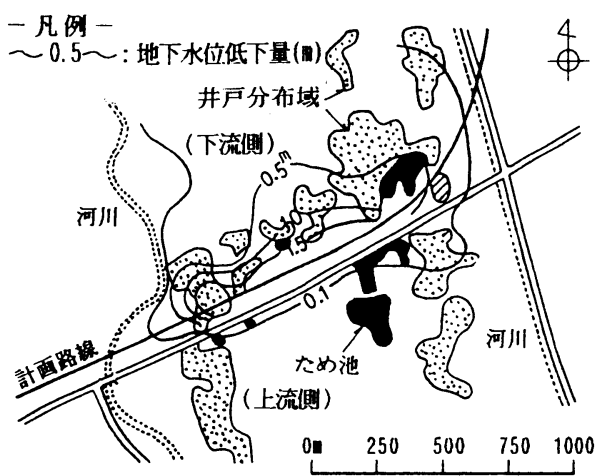

図ー7 シミュレーションによる地下水位低下状況 (無対策時)

表一２地下水位低下による水利用施設の機能障害

\begin{tabular}{|c|c|c|c|}
\hline \multirow{2}{*}{ 施 } & \multicolumn{3}{|c|}{ 井戸湛水深の減少度 } \\
\cline { 2 - 4 } & $50 \%$ 以上 & $10 \sim 50 \%$ & 合 計 \\
\hline 井 戸 & 19 & 83 & 102 \\
\hline ため池 & 貯水量の減少 : $21.000 \mathrm{~m}^{3}$ \\
\hline 水 $⿴ 囗 十$ 田 & かんがい期間の必要補給水量 : $230.000 \mathrm{~m}^{3}$ \\
\hline
\end{tabular}

\section{4. 広域地下水の数值解析}

\section{（1）目的及び解析条件}

道路建設による地下水流（主に自由地下水）阻害が 水利用施設に与える影響の予測と, 現状の地下水状態 に復元するのに必要な補給水量及び復水施設の規模を 事前に検討する目的で, 地下水モデルによる数值解析 を行った.

解析に当たっては, 降雨, 蒸発散, 直接流出, 地下 浸透までの主として地表付近の水循環を表す “地下水 涵養モデル”と, 帯水層内の地下水流動を表す地下水 流動モデル”を組み合わせて調查地全体の水循環を表 現した.

地下水涵養モデルは直列 3 段のタンクモデルで表現 し，計算期間は14ケ月間（日単位）とした。降水量は， 近傍の実測デー夕を, 蒸発散量は月平均気温をもとに ソーンスウェィト法により推定した值を用いた。 モデ ルの作成は，第 3 段タンクを飽和帯と見なし，その水 位が調查值の実測地下水位変動を再現できるよう各夕 ンクのパラメータを修正して行った．そして第 2 段夕 ンク（底穴）から第 3 段タンクへの流量を地下水涵養 量として求めた。

一方地下水流動モデルは，自由地下水を対象とした 平面 2 次元モデルで，解析領域は計画路線を中心とし て南北方向に約 $1500 \mathrm{~m}$, 東西方向に約 $1700 \mathrm{~m}$ （両端の

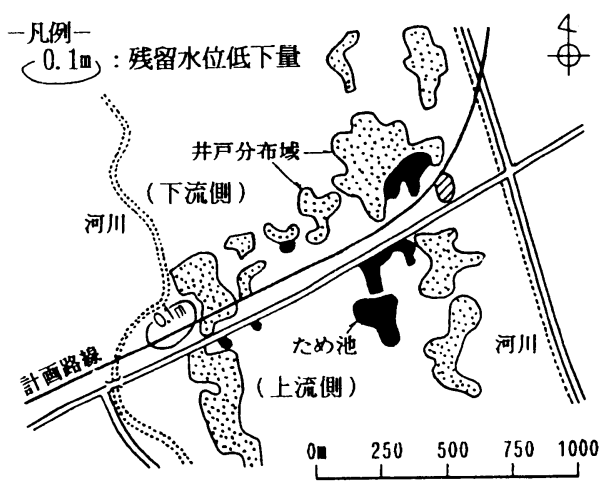

図ー8 シミュレーションによる残留水位低下状况 （100mピッチ及び200mピッチで注水した場合）

河川まで）の範囲である．そして大阪層群の最上位粘 土層を不透水層とし，帯水層構造，水理定数，地下水 位等に関するデータ及び地下水涵養モデルで得られた 地下水涵養量を用いてモデルを構築した。境界条件は， 南北端は動水勾配を一定, 東西端はそれぞれの河川水 位を固定水位条件として与えた。

モデルの作成に当っては, 調查地内で得られた地下 水位データの時間変動や平面分布形状が再現されるこ とを指標にパラメーターの固定を行った. なお，地下 水流動の支配要素の一つ之考えられる “水みち”につ いては，その具体的な位置が特定できなかった。 そこ で原位置での透水試験結果やボーリング結果による地 質状況の違いに着目して, 高透水性ゾーンという面的 な透水性区分を行って検討した。

\section{(2) 解析結果}

\section{a ）無対策施工による周辺井戸等への影槞}

図ー7に解析結果を示す. 同図によれば計画ルート 中央が掘削規模が大きいことに起因して地下水位低下 量が大きく，ルートから $100 \mathrm{~m}$ 範囲で $1.5 \mathrm{~m}$ 以上， $200 \mathrm{~m}$ の範囲で $1.0 \mathrm{~m}$ 以上の水位低下が起こり，0.5m以上の低 下筙囲は 600 mの籍囲に及ぶ。一方掘削深度が漸減する 両端部では水位低下範囲は縮小された形となるが，そ れでも $0.5 \mathrm{~m}$ 以上の水位低下範囲はルートから $200 \mathrm{~m} \sim$ 300mの範囲に及ぶ状況である.これに対し地下水流動 の上流に当る南側での地下水位低下はルート近傍に限 られており周辺の低下量は非常に小さい，即ち地下水 流動の下流側に当たる北側の地域では広範囲で著しい 水位低下が予想された。

このような施工に伴って予測される水位低下が周辺 の水利用施設に与える被害について定量的評価を行っ た. その結果を表一 2 に示す. 影響圈内（計画ルート から $300 \mathrm{~m}$ 範囲内) $の 132$ 所の井戸(全井戸の $42 \% に$ 当 たる.）の内，102ヶ所が井戸内水位の減少度が10\%以 
表一 3 地下水保全工法の選定

\begin{tabular}{|c|c|c|c|c|c|}
\hline 工法察 & 模 式 図 & 工法概要 & 施工性・信頼性 & 施工費 & 評価 \\
\hline 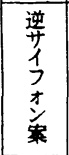 & 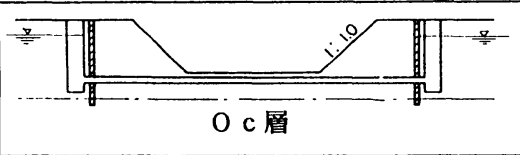 & $\begin{array}{l}\text { 上流側下流側の水頭差を利用 } \\
\text { して逆サイォン管を通して } \\
\text { 流下させる. 既存のカルバー } \\
\text { ト部 } 3 \text { 所と既設の送水管 } \\
(6600 \mathrm{~mm}) 7 \text { 所で対応. }\end{array}$ & 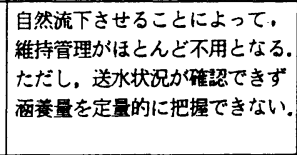 & 中 & 0 \\
\hline 梦 & $\sqrt{16}$ & 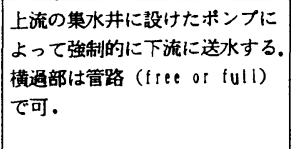 & 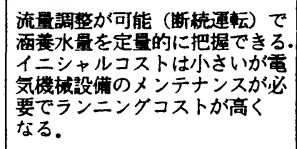 & 中 & $\triangle$ \\
\hline 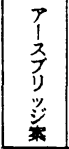 & $\mathrm{Oc}$ 眉 & 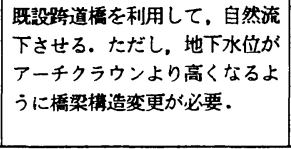 & $\begin{array}{l}\text { 造水壁によりせき上け効果から } \\
\text { 見て必必要水量の全部はカー゙ーで } \\
\text { きない. }\end{array}$ & 小 & $\triangle$ \\
\hline
\end{tabular}

上になり，何らかの影響を受けるものと判断された。 地下水位の低下に伴って影響を受けるため池は 9 所 あり, 眝水減少量の総量は約 $21000 \mathrm{~m}^{3}$ と予想された. また, 水田における減水深の増大に伴う必要補給水量 は，潅溉期を通じて約 $230,000 \mathrm{~m}^{3}$ となることが予測さ れた。

\section{b）必要復水水量及び必要施設規模}

当該区間の道路建設計画により分断される地下水 （自由地下水）は $250 \mathrm{~m}^{3} /$ day $(170 \ell / \mathrm{min})$ 之算定され た. すなわち『地下水環境の保全』の見地から道路建 設後の地下水状況を建設前之同様の状況に維持するた めにはこの水量を何らかの方法で分断された側（地下 水流の下流側）へ婳養させ復水する必要がある．この 場合帯水層への注水能力は帯水層の規模（厚さと広が り）・地下水位等の条件によって異なるため, 復水施 設の設置位置・間隔については詳細な土質データを必 要とする.

本解析では復水施設（涵養井）の設置間隔（ピッチ） を50m，100m,200mとした場合についてその効果を数値 解析により検討した。 その結果最も効果が大きいのは 50m の場合で, 全域で地下水位は原状に回復するが, この場合所々で地下水位が地盤より高くなり, 湿地化 を呈する状況となる．すなわち当地域では帯水層の注 水能力（注水された水が下流側へ掃けること）に限界 があり, 集中的な注水は逆に湿地化というマイナスの 効果をまねくため，ある程度分散して注水する方が実

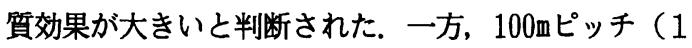
箅所当り $17 \ell / \mathrm{min}$ ) と $200 \mathrm{~m} ヒ ゚ ッ チ （ 1$ 箇所当り $34 \ell /$ min）の 2 ケースについては, 図ー8に示すように復 水の効果は両ケースとも同程度であり，一部地域で僅 かの水位低下域があるが, 全体としては水位はほとん どの地域で自然水位まで回復しており，本対策工の効

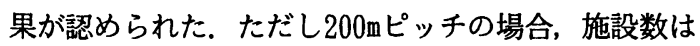
少ないものの，1基当たりのシステムの規模が大きく， 婳養井の有効半径を50m としなければならなくなり, 現実的でない. したがって涵養井は10箅所 (100mピッ チ）とし，1箇所あたりの集水と涵養の可能な設計流

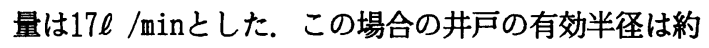
$10 \mathrm{~m}$ なるが, 施工面からの条件により本計画では井 戸半径を2mとし, 有効半径を拡大することと同等な勃 果が得られる方法を検討することとした.

\section{5. 地下水保全工法の検討}

\section{（1）地下水保全工法の具すべき条件}

永久構造物である道路に付帯する地下水保全工法の 具すべき条件は, 地下水の水質を変化させることなく, 長期的にかつ面的に下流側に安定して地下水の補給を 可能とすることである. すなわち, 以下の条件を満足 しなければならない。

(1)必要水量を地下水の形で供給する.

(2)目詰まりの発生を防ぐ.

(3)地下水流の不均一性を考慮し浸透面積を大きくする こと.

計画全体としては次の条件を満足する工法を選択し なければならない。

(1)地元への騒音, 水質等の環境問題を生じさせない工 法

\section{(2)道路用地内で対応可能な工法}

(3)信頼性が高い工法

(4)維持管理が容易な工法

(5)経済的に有利な工法

\section{（2）地下水保全工法の選定}

地下水保全工法は，阻害された地下水を現状の状態 に復元することを目的とする. したがって工法選定に 当っては表一 3 に示すように, 以下の 3 つの送水方式 案を検討した。 


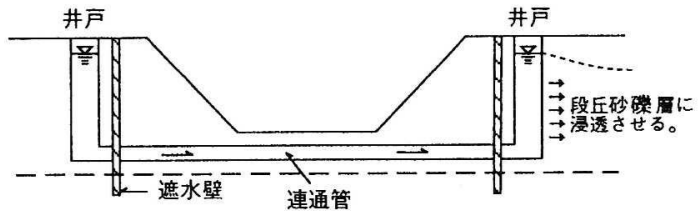

Oc大阪層群粘土層

Og大阪虽群砂喽層

図-9 地下水保全工法の概念（1 ユニット）

(1)逆サイフォン案

(2)ポンプ案

(3)アースブリッジ案

下流側へ地下水を供給する方法は, 将来の維持管理 を考えメンテナンスフリー化を目指し，自然流下の状 態で送水することを基本とした.

方法として「上げ越し」あるいは「下げ越し」の 2 通りある. 上げ越しの場合には,

i）ポンプアップによる強制送水方式は維持管理が必 要であり, ランニングコストがかかる.

ii）跨道橋を利用した自然流下の場合は地下水位をア ーチクラウンより高くなるように跨道橋の構造変更が 生じ, かつ跨道橋の数が限られていることから下流側 で必要な水量をカバーできない.

上記の事より，自然流下で送水する方法として「下げ 越し」（逆サイフォン形式）による方法を採用するこ ととした。

\section{（3）地下水保全工法の基本形式の決定}

上記（1）及び（2）の方針により図ー9に示す 『逆サイフォン方式』の復水工法を基本とした地下水 保全工法を立案した. 本工法は以下のシステムを 1 工 ニットとし, 複数のユニットを現地に構築することで 必要復水量に対応させるものである.

1 ユニットの基本構造は以下のとおりである.

(1)道路切土路肩部に切土法面の安定確保及び動水勾配 を確保するため柱列式地下連続壁を設置する。

(2)柱列式地下連続壁背面には，地下水上流側に集水施 設（集水井），下流側に涵養施設（涵養井）を設置し， 集水施設と涵養施設を連通管で結ぶ.

(3)井戸の有効半径を拡大する手法, また地盤の不均一 性を考慮し, 浸透断面積を大きくする手法を検討し, 本システムに付加することとする.

\section{（4）浸透断面積を大きくする手法の検討}

地下水保全工法のポイントは, 地下水をいかに面的 にかつ長期的に安定した状態で上流側から下流側へ浸 透させることができるかである.このため, 地下水上
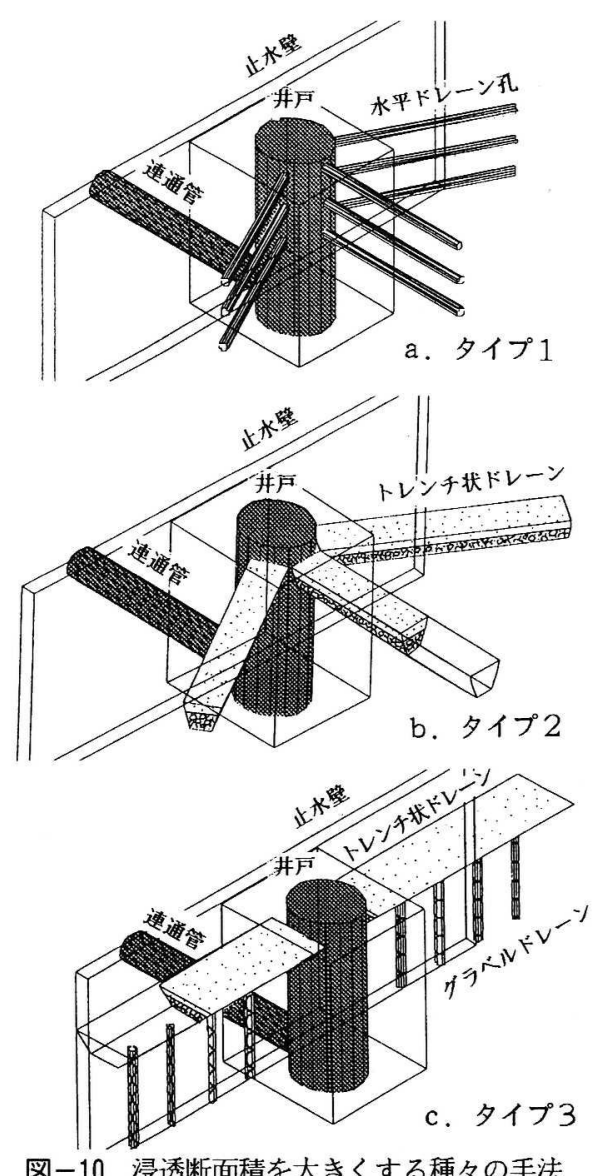

図-10 浸透断面積を大きくする種々の手法

流側の集水施設及び下流側の涵養施設の構造決定に際 しては, 対象土層の性状や目づまり現象発生の有無を 十分考慮すべきであり, 現段階で想定される種々の集 水・涵養施設を実際に現地で設けてその効果を事前に 検討し最適な手法を選定する必要がある，選定時には 次の事項も考慮しておく必要がある.

(1)涵養対象となる段丘砂砅層の土層変化に対応できる ように，平面的に連続した浸透が期待できること. (2)できるだけ自然に近い動水勾配で涵養できること. (3)施工性, 及び経済性の面で有利であること. これらの事項より図ー10に示す 3 案を集水井及び涵養 井に付加する手法として検討した.

タイプ 1 : 集水井及び涵養井から放射状に水平ドレ ーン孔を設置して井戸の有効半径を大きくする案

タイプ $2:$ 上記ドレーン孔の代わりにより浸透断面 積がより大きいトレンチ状ドレーンを地表部付近に放 射状に設置して井戸の有効半径を大きくする案

タイプ $3:$ 止水壁に沿ってトレンチ状ドレーンとさ らに鉛直方向にグラベルドレーンを設置して, 深度方 向の浸透域を拡大する案

さらに各基本形を組合わせた以下の 3 案を付加して 

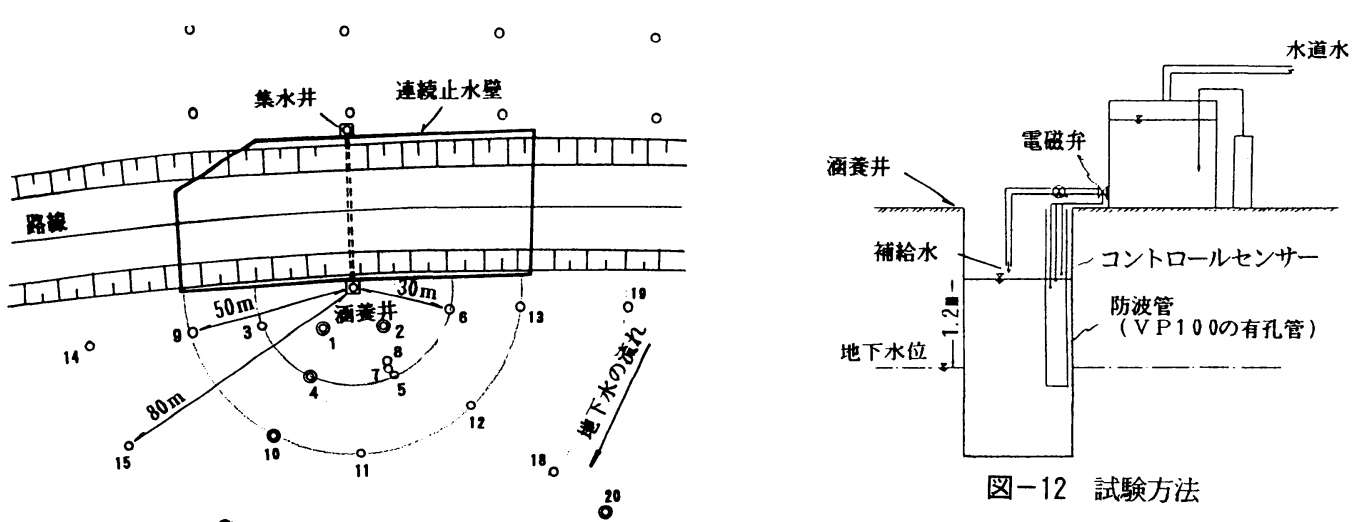

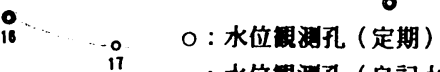

図-12 試験方法

○：水位㹕泪孔(自記水位計) 1 20: 下流俔の観泪孔

図-11試験施工位置図

計 $6 つ の$ 施設タイプを検討した.

タイプ $4:$ :イプ 2 とイプ 3 の組合せ

タイプ 5 :タイプ1とタイプ 3 の組合せ

タイプ $6:$ タイプ 1 とタイプ 2 とタイプ 3 の組合せ いずれも集水井及び婳養井の有効半径を拡大するこ之 を目的としたものであるが，その最適構造を決定する にあたっては効果の大小は勿論のこと, 施工性や維持 管理の問題も含めた多面的な評価が必要となる.

タイプ 1 は地すべり対策で一般に用いられている集 水井之同種のものであり，施工実績は豊富である．た だし井戸内からの施工となるため施工性が良くないこ とや, ドレーンパイプの延長及び孔配置の決定方法に は不明確な点も多い.

タイプ 2 は地上からトレンチ掘削するため施工性に は優れているが，用地的な制約条件もあって，施工規 模は限られる.一方タイプ 3 は，連続的な施設である ため前記 2 タイプの方法に比べて浸透断面積はかなり 大きくなり，また柱列止水壁沿いに施工するため用地 上の制約も少ない．ただし，グラベルドレーンの孔径 やピッチの決め方, 更には施設規模が大きくなるため 維持管理が難しいといった問題もある. しかし, 目詰 まりが発生すると新たにグラベルドレーンを打設しな おすことによって地上から修復できる利点がある.

このように各施設の構造的な問題について詳細に検 討する必要があるが, この他，使用する材料（例えば フィルターの材質や粒径），目詰まり対策，涵養勃果 を評価する方法等今後解決すべき問題も多い.

\section{6. 復水工法の効果確認のための試験施工}

\section{（1）試験施工の目的}

選定された逆サイフォン方式の復水システムが, 現

）地の砂磷層地盤に対してどの程度の効果をもたらすか を確認するために実際規模の地下水補給施設を現地に 設けて復水効果を事前に検討し, 最適な施設形状を決 定することを目的として試験施工を実施した.

\section{（2）試験施工方法}

図ー11に示すように対策工区間に延長100mの柱列式 地下連続壁及び地下水集水, 婳養施設を設置した。 た だし止水壁施工区間が有限長であったため, 止水壁両 端からの地下水の回り込みが生じ, 止水壁を挟んだ上 下流間で十分な水位差が得られないことが予想された。 そこで連通管内に遮水弁を取り付け, 下流側井戸と上 流側井戸を分離し，下流側井戸 (涵養井) で涵養効果 試験を実施した。

試験は, 涵養井内に注水して水位を上昇させ, 周辺 地下水との間に人工的な水位差を設けて涵養させるも ので, 図ー12に試験の概要を示す. また具体的な試験 手順は次のとおりである.

(1)地上の給水タンクに水道水を眝水する. なお目詰ま り原因として考えられる水道水中の溶存酸素を地下水 と同一にするため, 窒素ガス $\left(\mathrm{N}_{2}\right)$ を送気し抜気 (脱酸素)した。

(2)井戸内の水位は, 『柱列式地下連続止水壁を全区間 施工後に生じる上下流での水位差』とし, 数值解析結 果を基に, 『周辺地下水位 $+1.2 \mathrm{~m}$ とした. ここに 周辺地下水位とは涵養井近傍に設けた地下水観測孔 4 地点の平均水位とした.

(3)涵養井水位のコントロールは，井戸内に設置したリ レー式センサーと給水タンクに取り付けた電磁弁を接 続して, 水位が士 $2.5 \mathrm{~cm}$ の精度で維持されるように給 水タンクから自動送水した。

\section{（3）試験ヶース}

涵養施設としては前記した6タイプを検討したが， 本試験施工では基本タイプについてその効果を比較検 討するものとし，このうち用地及び時間的な制約から 

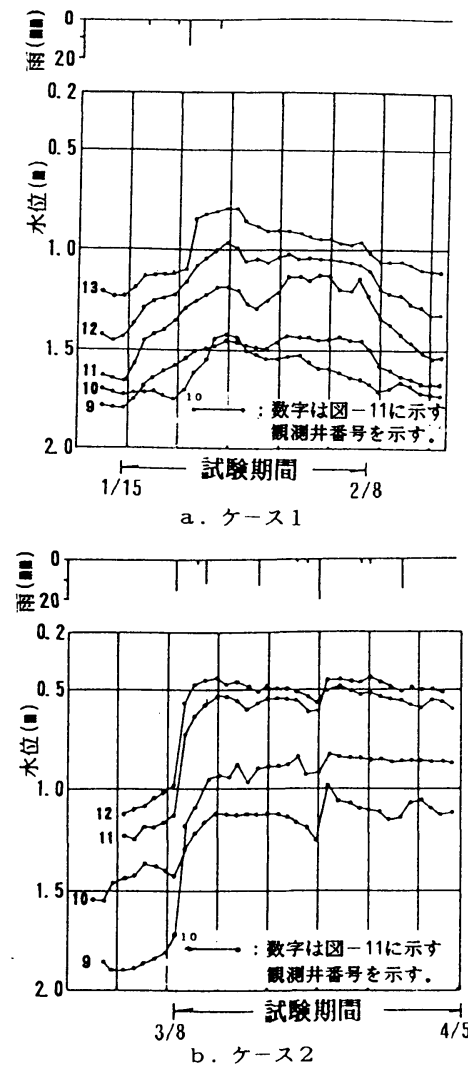

図-13 試験期間中の地下水位变動状況
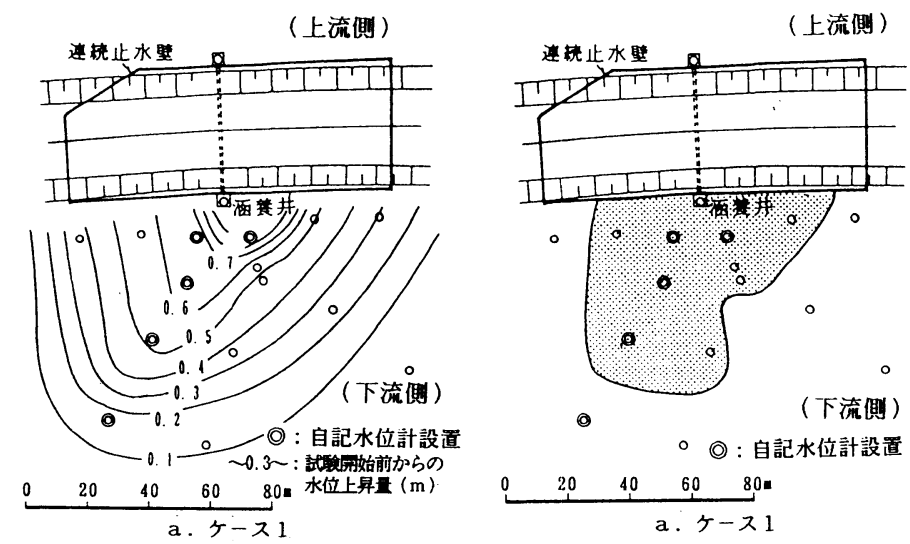

（上流側）

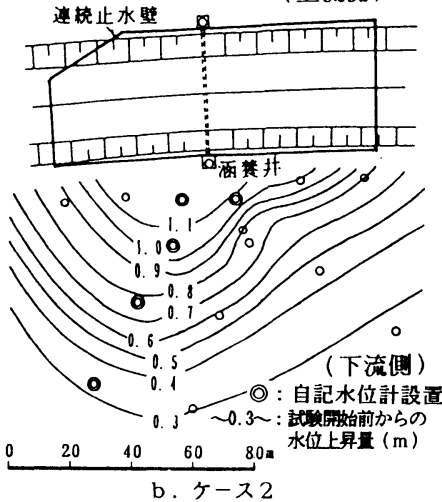

（上流側）

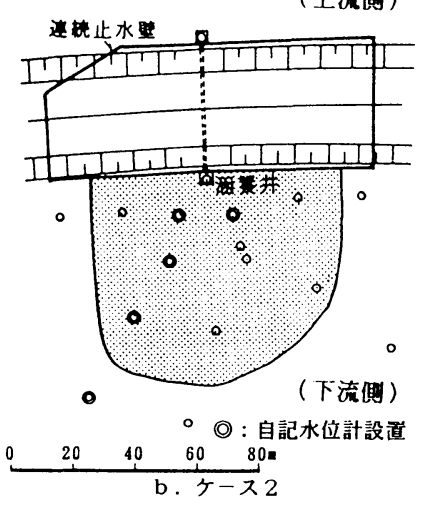

図-14 地下水位上昇量の平面分布 図ー15 トレーサーの到達範囲 ( 1 ヶ月後)

以下の 2 ケースについて試験を実施した.

(1)ケース1（タイプ1の水平ドレーン方式）:

涵養井から放射状に水平ドレーン孔（ $\phi 86 \mathrm{~mm}, \mathrm{~L}=10 \mathrm{~m})$ を 3 方向上段, 中段及び下段の 3 段, 計 9 本設置し涵 龔させる方法。

(2)ケース2（タイプ 3のトレンチグラベルドレーン方 式) :

涵養井から柱列式地下連続壁沿いの地表部付近にト レンチドレーン $(\mathrm{L}=50 \mathrm{~m})$ と $2 \mathrm{~m}$ ピッチのグラベルドレ ーン ( $\phi 500 \mathrm{~mm}, \mathrm{~L}=3 \mathrm{~m})$ を設置し涵養させる方法.

\section{（4）観測体制}

\section{a ) 地下水位観測}

試験施工区間の上流側11ヶ所, 下流側20ヶ所の計 31 ヶ所に地下水位の観測孔を設置した.このうちの 6 ヶ 所は自記水位計による連続観測を行ない，他は1回／ 日の測定とした. また近傍 3 ヶ所のため池についても, 1 ヶ所は自記水位計により，他は 1 回／日の測定を行 なった。

\section{b) トレーサー追跡調查}

婳養井内にトレーサー（NaCl）を投入し，その到達
状況から涵養施設の影響（効果）範囲を評価した。調 查は各観測孔で一定時間毎に孔内水の電気伝導度を测 定するもので，その経時変化からトレーサーの到達の 有無を確認した。

\section{c）地下水垂直検厂}

涵養井近傍の観測孔 2 ヶ所で各ケース 2 回実施し, 地下水の流動状況を比較した。

\section{（5）試験結果}

a）地下水位変峌状況

試験期間中の地下水位変動状況として, 図一13に酒 養井から $50 \mathrm{~m}$ 離れた観測孔群の結果を示す.

(1)ケース 1

試験開始前約 2 週間の連続した無降雨日により，周 辺地下水位は単調に低下する状況にあった。 しかし試 験開始とともに水位は上昇に転じ，この傾向は涵養井 に近い観測点ほど顕著に現れた，具体的には，涵養井 から $30 \mathrm{~m}$ 以内の観測地点では試験開始直後から急激な 水位上昇を示し, 直近の観測孔では0.7〜0.9mの水位 上昇量を示した. これより遠い30～ $50 \mathrm{~m}$ の範囲では水 位上昇の程度はやや小さくなるが, 地下水位は徐々に 
上昇し，ほぼ7日目以降には一定の水位となった。涵 養井から $80 \mathrm{~m}$ 付近の観測孔では降雨（13mm/日）によ る一時的な水位上昇はあったが，50mの範囲で見られ た安定した水位上昇は認められなかった。 ただし試験 前から継続していた水位低下傾向は止まり，ほぼ横ば いの水位変動を示す状況にあった。

(2)ケース 2

試験開始直後から, 全ての観測地点で明らかな水位 上昇を示した．涵養井から $30 \mathrm{~m}$ の範囲では涵養開始と 同時に $1 \mathrm{~m}$ 程度の大きな水位上昇を示し， $2 \sim 3$ 日目 以降にはほぼ定常状態となった. 30〜 50mの範囲でも 水位上昇の程度はやや小さくなるが, 同様に顕著な水 位変動を示した。一方 $80 \mathrm{~m}$ 離れた観測地点では水位は 緩やかに上昇し， $5 \sim 7$ 日目位で $0.3 \mathrm{~m}$ 程度の上昇量を 示すなど, ケース1では見られなかった復水効果が認 められた.なお, 試験期間中には $10 \mathrm{~mm} /$ 日以上の降雨 日が 5 日あったが, これによる水位の変動は涵養井に 近い観測孔程小さく, 試験による涵養効果の方がより 大きく影響しているものと思われる.

以上のように, 試験開始直後の地下水位変動は何れ のケースも明らかな上昇傾向を示し, 涵養施設による 復水効果が認められた. ただし水位上昇の程度は, 施 設タイプによって異なっている. 図一14は各観測地点 の水位上昇量（試験中の安定水位之試験前水位の差） を平面図にコンター表示したものである.これによる と水位上昇の䉇囲は, 涵養井を中心にして下流側に半 円状に拡大している状況が読み取れるが，ケース1に 比べてケース 2 の方が大きくなっている. また涵養効 果の到達範囲は, 『点』で婳養させるケース 1 よりも 『線』で婳養させるケース 2 の方が面的に広いことが 解る. $0.5 \mathrm{~m}$ の水位上昇を示した範囲は涵養井からの距 離で, ケース 1 が最大約 $50 \mathrm{~m}$, ケース 2 が最大約 $65 \mathrm{~m}$ であったが，ヶース2では東西方向にも大きく広がっ ており, 面積的にもより広範囲で復水効果が現れてい る. 当然の事であるが, 涵養施設付近の動水勾配も小 さくなり，目詰まりしにくくなる.

b ) トレーサー追跡調査

調查結果を図ー15に示す．影響範囲はケース 1 では 井戸を中心に楕円状に，ヶース 2 では方形状に拡大し ている. その範囲はケース 1 に比較してケース 2 の方 が面的に大きくなっている.このような状況は地下水 変動量の平面分布形状（図一14）とも概ね一致したも のとなっている.

\section{c）地下水垂直検厤}

試験結果を図ー16に示す．試験前は，GL-7mまでの 砂礫層及び砂層の区間で地下水が流動している状況が 読み取れ，特にGL- $5 \mathrm{~m}$ までの段丘磷首で卓越した流動 が認められた。 ケース毎の検層結果を比較すると，
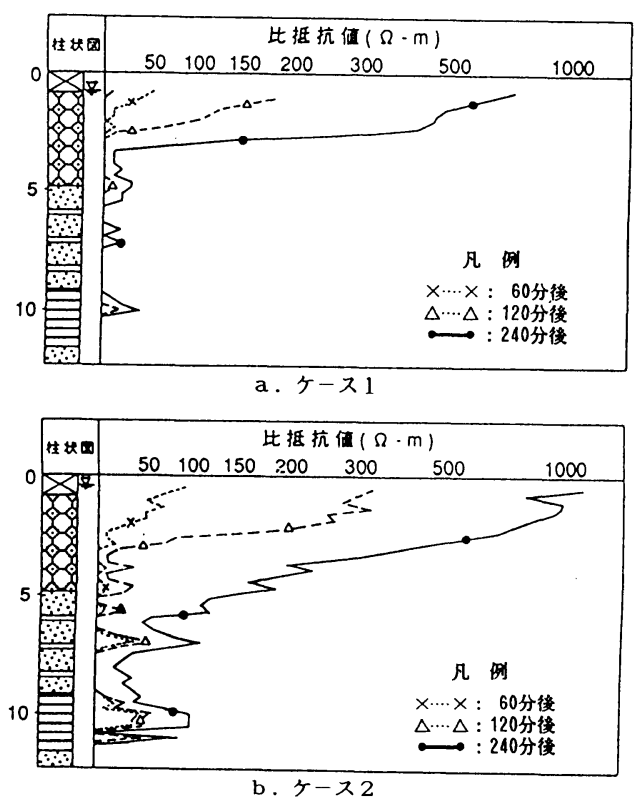

図-16 地下水垂直検層結果

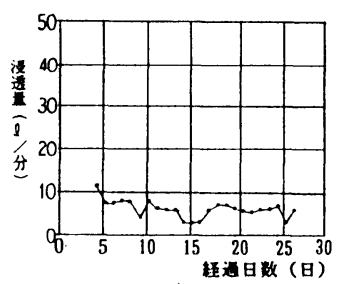

a. ケース 1

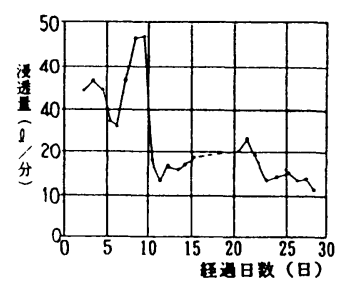

b. ケース 2
図-17 浸透量の経時变化

ケース 1 よりケース 2 の方が地下水の流動状況は顕著 である. ケース 1 での卓越流動区間は浅部のGL- $4 \mathrm{~m}$ 付 近までであるが，ケース 2 ではGL-7m付近までの区間 で地下水流動が見られる.

このような涵養施設の違いによる地下水流動状況の変 化は, 前述の水位変動の傾向とも整合している.

\section{d) 涵養量}

涵養施設からの浸透量は, 図ー17に示すように試験 初期は大きく, 周辺地下水位の上昇に伴って漸減し, 水位の安定とともに一定の浸透流量を示すようになる.

(1)ケース 1

試験期間中概ね安定した浸透流量を維持しており, 最終的な浸透流量は 6 e / / minであった。

(2)ケース 2

試験開始直後に $30 ４ 0 \boldsymbol{l} / \mathrm{min}$ の浸透流量を示したも

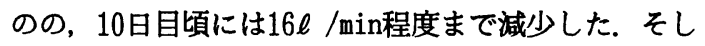
て試験期間中に近傍の水路から漏水が発生したりして, 地下水位が変動して, 浸透流量自体は大きく変動した. 最終的な浸透流量は $10 \ell /$ minとなった。 


\section{7. 地下水復水施設の評価}

\section{（1）現地盤への適用性}

試験施工において, 2タイプの涵養施設の効果を比 較検討した. 効果判定の指標としては，(1)地下水位の 回復量，(2)影響範囲，(3)涵養量の 3 要素が考えられる が, どの範囲でどの程度の効果を見込めば対策施設と して有効であるかの判断が重要な点となる.

試験施工結果によれば，『面』で涵養させるケース 2が『点』で涵養させるケース 1 に比して上記(1) (3) のすべてにおいて有効であることが確認された．特に ケース 2 の涵養量については，主たる支配要因である 周辺地下水位が降雨等により上昇する傾向にあり涵養 条件はむしろ劣っていたことを鑑みても，ケース1よ り大きな効果が期待できることがわかる.

このように両方の涵養施設とも，程度の差はあれ有 為な復水効果を示した．また，涵養量も10日から 1 か 月間ほとんど低下していない，これは婳養に際して， 井戸内の水位を自然状態に近い水位に維持し，地下水 位との動水勾配を大きく取らなかったため，涵養に際 して最も懸念した目づまりが生じなかったことになる. 過去の復水工法の実施事例を見れば，対象地盤の透 水性は $10^{-1} \sim 10^{-3} \mathrm{~cm} / \mathrm{sec}$ 範囲にあり, 井戸 1 本当り の注入実績は透水性の大小に支配されているようであ る. 試験施工地点の地盤の透水性は上記範囲の低透水 域に相当するが，水平ドレーン孔やトレンチ・グラベ ルドレーンを併設して井戸の有効半径を大きくしたこ とにより，自然状態に近い地下水の流れが再現できた ものと考えられる. 即ち $10^{-1} \sim 10^{-3} \mathrm{~cm} / \mathrm{sec}$ 透水性を 有する砂〜砂磷地盤に対して，本検討で選定した地下 水復水工法は十分適用できると評価される.

なお試験施工を実施した位置での F E Mによる断面 2 次元浸透流解析の結果によれば，施工に伴う下流側 への必要補給水量は締切り長さ $100 \mathrm{~m}$ 当り $13 \boldsymbol{l} /$ minであ り，ケース 2 の最終浸透量 $10 \ell / \min$ と概ね一致してい る. そしてこの不足水量については，例えばトレンチ ドレーンの施工延長を伸ばすといった施設規模の拡大 によって対応することが可能である.

\section{（2）集水・涵蒦施設の形状決定}

永久構造物である道路に付帯する復水施設としては, 地下水を長期的にかつ面的に安定した状態で集水・涵 養を維持することが必要である．このためには地下水 状況を可能な限り自然に近い状態に保持することが必 要であり,これにより目詰まりの発生を極力抑えるこ とができる.したがって小さな動水勾配で広範囲に均 等に復水するためには集水・涵養面積を大きくするこ とがきわめて重要であることがわかる。
また，一般には層状水として取り扱われる砂〜砂磁 首中の地下水も，『局所的な水みち』と呼ばれる高透 水性ゾーンに支配されて流動していると考えられるこ とから，この高透水性ゾーンを捉える確率を高めるた めにも涵養面積を大きくする必要がある.

以上のことから，施工性も考慮し，本工事での復水 工法の形状はケース 2 を採用することとした。

\section{8.まとめ}

本研究では, 広域かつ長期間の水文調查を実施し掘 割の道路建設に際して問題となる地下水の流況阻害を 未然に防ぐ目的で復水工法の検討を行った。 その中で 復水工法に係る種々の問題点が提起された。 そこでそ れらの問題点を克服して恒久的な施設とするためにど のような施設が最適であるかを検討した．その結果以 下に列挙する結論を得た。

（1）筧乱した原位置の試料を対象に室内での長期 （2ヶ月）の浸透実験を実施した。 その結果, 目詰ま りには動水勾配がもっとも大きく関与することがわか った.

（2）対象地区の水文地質情報が詳細に判明すれば, 復水工法の効果や施設配置に関する検討において数值 解析は有効である。

（3）現状の流況を維持し，自然流下方式で維持管理 が容易な工法を用いることとし，その結果本地区では 逆サイフォン方式が有効であると判断された。

（4）地下水の浸透は一様でないと言う観点之涵養施 設の近傍で高い動水勾配をかけると目詰まりしやすい との観点から，涵養施設の浸透断面を広くする種々の 工法を提案し検討した。 そして原位置において実際規 模の涵養施設による試験施工を実施した。 その結果, 柱列止水壁沿いに設けた集水・涵養井戸（本件では $100 \mathrm{~m}$ 間隔) と連結したトレンチ掘削と, グラベルド レーンを併用する方法が用地の面および涵養効果を拡 大するうえでも有効であり，目詰まりした後の修復が 可能であることがわかった.

なお，今後の課題としては，本工法はその機能を恒 久的に維持する必要があることから，井戸の仕上げを 入念に行い，目詰まりによる機能低下を最小限に㧕え， モニタリングを継続して必要に応じシステム全体のフ ラッシング (逆洗) を行い，その機能を維持していか なければならないが, システムの機能を評価するため の手法の検討, 及び維持管理方法等を詳細に決定して いく必要がある.

近年, 地下空間あるいは地下水環境に関する議論が 多くなされており ${ }^{4)}$ ，今後地下水の予測・評価技術と して, 地下水シミュレーション解析技術の向上や地下 
空間における地下水流阻害や地下水障害の防止, 地下 空間内の水制御技術，地下水のモニター技術等を確立

していく必要があると言われている.

本工法で企画・立案した技術・手法が将来地下水環 境の保全, あるいは今後増大していくと考えられてい る大深度地下利用等に関わる技術進歩に僅かでも貢献 できれば幸いである.

\section{参考文献}

1）土質工学会 : 根切り工事と地下水, pp.313-317，1991.

2）西垣誠: 被圧水及び高地下水位地域での基礎工の設計
と施工の問題点, 基礎工, Vol.18, No.8, pp. 26-32, 1990.

3）永井宏ほか：連続切土区間の地下水保全について，第 19回日本道路会議論文集, pp.160-161，1991.

4）鎌田烈ほか: 水文…地下水脈, 土之基礎, Vol.41, pp. 7-12, 1993.

5）水収支研究グループ編：地下水資源・環境論，共立出 版, pp.229-271，1993.

6）村下, 永井: 人工地下水用井戸の目づまり，日本地下 水学会誌, 第 14 巻, 第 2号, pp.11-14, 1972.

(1994.1.12 受付)

\title{
A STUDY ON PRESERVATION METHOD OF GROUNDWATER-FLOW IN HIGHWAY CONSTRUCTION
}

\author{
Hiroshi NAGAI, Makoto NISHIGAKI, Takao UNO \\ and Mitsunori YANAGIDA
}

The highway is designed to cross a wide terrace by open-cutting with the $1.3 \mathrm{~km}$ in length, $8 \mathrm{~m}$ deep, which will incur dewatering of the terrace deposits, aquifer, downstream of the highway. Facility to preserve groundwater-flow is designed as countermeasure against cutting off the flow after making clear the groundwater condition and proving efficiency of the facility by means of simulation and full-scale model test.

The facility consists of discharge well upstream the open-cut, recharge well downstream it, and connecting pipe below it and between both wells. Both the discharge and recharge wells $(2 \mathrm{~m}$, $12 \mathrm{~m}$ deep) are furnished with trenches $(1.5 \mathrm{~m}$ wide, $2.5 \mathrm{~m}$ deep, $20 \mathrm{~m}$ to $80 \mathrm{~m}$ long) provided in parallel with the cut-off walls and pits $(0.5 \mathrm{~m}, 3 \mathrm{~m}$ deep) provided at $2 \mathrm{~m}$ intervals beneath the trenches, so as to complement efficiency of the wells. 